\title{
Study on Cranial and Caudal Mesenteric Arteries in Opossum (Didelphis albiventris)
}

\author{
Estudio de las Arterias Mesentéricas Craneal y Caudal del Zorrillo (Didelphis albiventris) \\ José Ricardo de Carvalho Pinto e Silva; Márcia Regina Fernandes Boaro Martins \& Joffre Guazzelli Filho
}

\begin{abstract}
PINTO E SILVA, C. J. R.; MARTINS M. R. F. B. \& GUAZZELLI FILHO, J. Study on cranial and caudal mesenteric arteries in opossum (Didelphis albiventris). Int. J. Morphol., 26(3):635-637, 2008.

SUMMARY: The objective of this study is to describe the cranial and caudal mesenteric arteries in 10 opossuns after Neoprene latex injection. The cranial mesenteric artery arises from the abdominal aorta, caudally to the celiac trunk, originating the caudal duodenal pancreatic artery, middle and right colic, jejunal and ileocecocolic arteries. The caudal mesenteric artery arises from the aorta, cranially to the external iliac arteries, originating the cranial rectal and left colic arteries.
\end{abstract}

KEY WORDS: Anatomy; Opossum; Mesenteric arteries.

\section{INTRODUCTION}

Considering that the anatomical knowledge is necessary to understand the biological functions, a macroscopic study on the cranial and caudal mesenteric arteries was carried out, aiming at increasing the anatomy knowledge compared with other animals.

Studies with rats carried out by Greene (1955), Farris \& Griffith (1949) and Cook (1965) stated that in these animals the upper mesenteric artery is a great vessel that comes from the aorta abdominal portion, originating a lower pancreatic-duodenal branch which extends to the pancreas and duodenum and several branches to the jejunum and ileum, cecum and colon.

Barone et al. (1973) in rabbits, Orsi et al. (1975) in golden hamster, Cook in guinea pig and Habel \& Stronberg (1982) in rats, stated that the cranial mesenteric artery arises from the aorta, caudally to the celiac artery, originating branches towards caudal direction, while the caudal mesenteric artery arises from the bifurcation of the abdominal aorta or from the right common iliac artery, and, sometimes, from the left one.

\section{MATERIAL AND METHOD}

Ten animals (Didelphis albiventris) from Botucatu region were used, previously authorized by IBAMA (licence 033/2001 and 50/2002).
Neoprene latex 450 was injected in the common carotid artery, then the animals were fixed in formaldehyde $10 \%$ for further dissection of the abdominal aorta, cranial and caudal mesenteric arteries.

\section{RESULTS}

In all the samples of opossuns (Didelphis albiventris) of this research was verified that the cranial mesenteric artery arises from the abdominal aorta ventral face, caudally to the celiac trunk.

Regardless its origin, the cranial artery directs ventralcaudally and sends as a branch the pancreatic-duodenal caudal artery, and a varied number of pancreatic branches (Fig.1). The middle colic artery, as observed in all the animals, irrigates the large intestine, that is, the left colon and cecum, anastomising with the left colic artery (Fig. 1).

The right colic artery, right branch of the cranial mesenteric artery, after a short way irrigates the right colon and anastomises with the ileocecocolic artery.

The jejunal arteries that come from a common trunk give a varied number from 6 to 15 branches that anastomise among themselves (Fig. 2). 


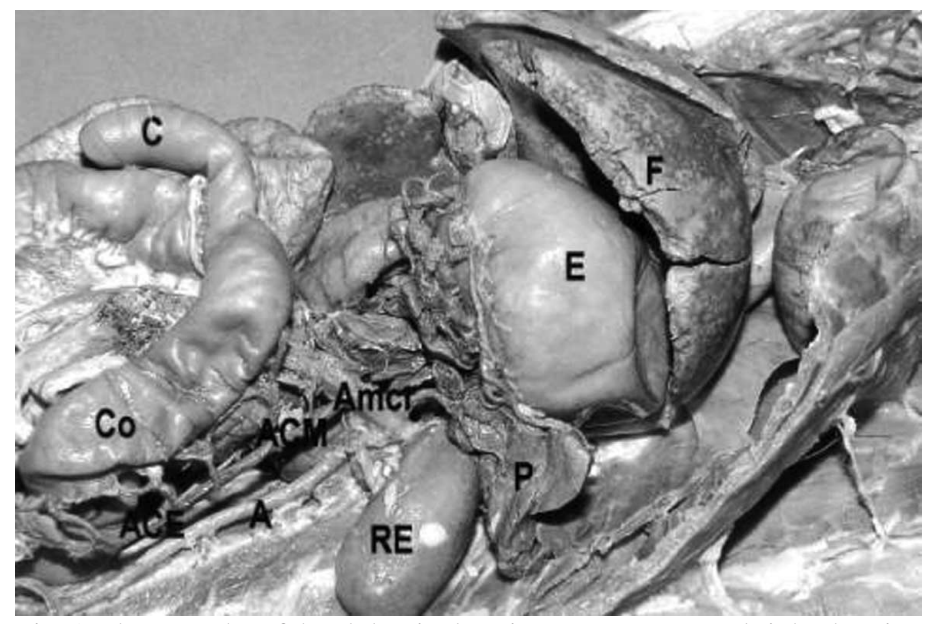

Fig. 1. Photography of the abdominal cavity, opossum ventral sight showing the stomach (E); liver (F); pancreas (P); left kidney (RE); cecum (C); colon (Co). It also shows the aorta artery (A) origim of the cranial mesenteric artery (Amcr); middle colic artery (ACM), left colic artery (ACE).

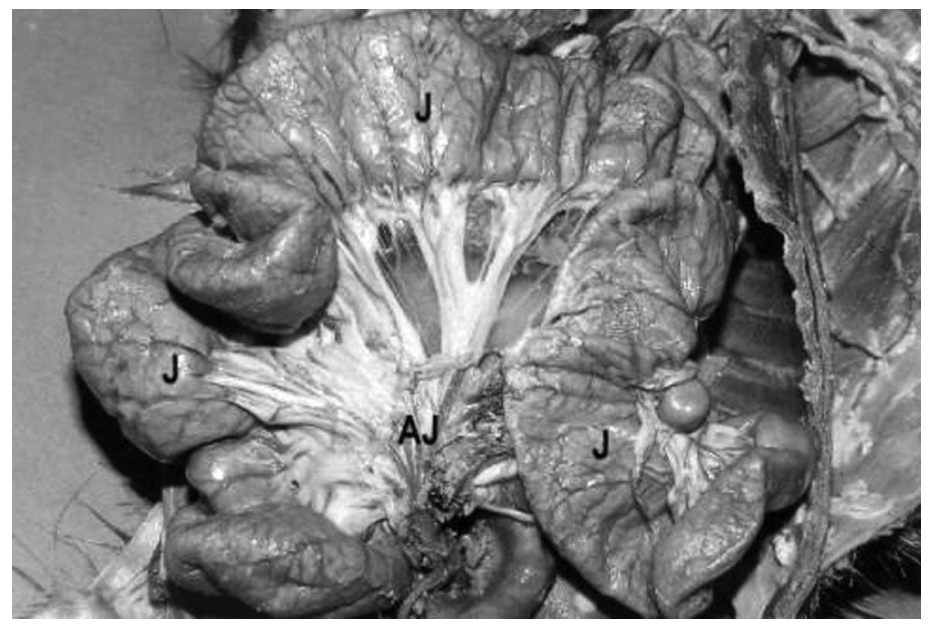

Fig. 2. Photography of the abdominal cavity, ventral sight showing the jejunum $(\mathrm{J})$ and the jejunal arteries displacement (AJ).

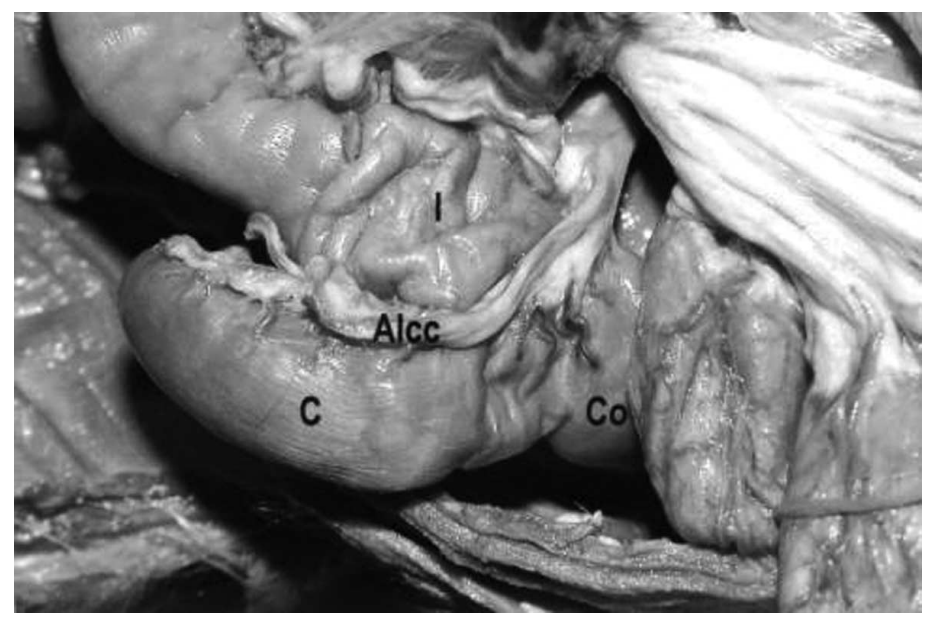

Fig. 3. Photography of the abdominal cavity, ventral sight showing the ileum (I); cecum (C); colon (Co); ileocecocolic (AIcc).
The ileocecocolic artery that is present in all the cases emits branches for the ileum, cecum and right colon (Fig.3).

Yet, the caudal mesenteric artery, after arising from the abdominal aorta ventral face, immediately cranial to the external iliac arteries emission, divides into two branches, cranial rectal artery that sends branches to the large intestine terminal portion, and the right colic artery, which in its cranial path through the descending colon wall anastomises with the descending branch of the middle colic artery (Fig. 1).

\section{DISCUSSION}

Comparing our results with those by Lebre (1923), we accept what the author says about the carnivores as for the mesenteric artery division. Concerning the data of Greene, in rats, the comparison is related to where the author refers to a series of intestinal branches for the jejunum, ileum, colon and cecum, without specifying the arrangements.

We can not disconsider Cook description in rats, and Barone et al. in rabbits, who noticed the cranial mesenteric artery emitting branches such as middle colic artery, caudal pancreatic-duodenal, right colon, ileocecocolic branch and jejunal arteries.

At studying branches in golden hamster, Orsi et al. do not mention the arrangements of the cranial mesenteric artery initial portion as for the vessels identification and distribution.

On the other hand, Habel \& Stronberg state that in rat the cranial mesenteric artery originates a double middle colic artery and a caudal pancreaticduodenal artery.

As for the middle colic artery described by Nayar et al. (1983) as a branch of the cranial, it was found by us as a similar result the ileocecocolic and pancreatic-duodenal cranial arteries.

Concerning the caudal mesenteric artery, which bifurcates into a left colic artery and a cranial rectal artery, the findings by Barone et al.; Orsi et al.; Habel \& Stromberg and Nayar et al., respectively, in rabbit, hamster and rat are confirmed. 
Related to the caudal pancreatic-duodenal artery which vascularizes the pancreas duodenum, such displacement had already been observed by Greene in rat, and Orsi et al. in hamster.

Whereas, we verified the middle colic artery directing to the left colon as found by Greene in rat.

For Orsi et al. and Habel \& Stromberg, it irrigates only the transverse colon. The right colic artery that irrigates the right colon and anastomises with the ileocecocolic artery seen in our animals, appears in rats sometimes in a common trunk with the ileocecocolic artery, Greene, and only supplies the ascending colon. The same was observed by Orsi et al. and Habel \& Stromberg in rat, being that in this case, the authors refer to the anastomosis with the jejunal arteries.
Barone et al., in rabbit and Orsi et al., in hamster, had already described the jejunal arteries derived from a trunk, although with different numbers.

It was verified in this study that the ileocecocolic artery emitted branches for the ileum, cecum and right colon, and that Greene referred to a ileocolic rather than a ileocecocolic artery, which is referred by Barone et al.. in rabbits.

However, for the distribution of branches originated from the caudal mesenteric artery, we verified the emission of a cranial rectal and a left colic arteries, restricting only to the left colon, what was cited by Orsi et al. and Haber \& Stromberg in hamster and rat, respectively.

PINTO E SILVA, C. J. R.; MARTINS, M. R. F. B.; GUAZZELLI FILHO, J. Estudio de las arterias mesentéricas craneal, caudal del zorrillo (Didelphis albiventris). Int. J. Morphol., 26(3):635-637, 2008.

RESUMEN: El objetivo de este estudio fue describir las arterias mesentéricas craneal y caudal de 10 zorrillos después de la inyección de látex Neoprene. La arteria mesentérica craneal tiene origen en la aorta abdominal, caudalmente al tronco celíaco y da origen a las arterias: pacreáticoduodenal caudal, cólica media derecha, yeyunales e ileocecocólica. La arteria mesentérica caudal con origen en la aorta, cranealmente a las arterias ilíacas externas, da origen a las arterias rectal craneal y cólica izquierda.

PALABRA CLAVE: Anatomía; Opossum; Arterias mesentéricas.

\section{REFERENCES}

Barone, R.; Pavaux, C., Blin, P. C. 6 Cuq, P. Atlas d'anatomie du lapin. Paris, Masson \& Cie Édit., 1973. pp.113-45.

Cook, J. M. The anatomy of the laboratory mouse. London, Academic Press, 1965. pp. 87-8, 1965.

Farris, J. E. \& Griffith, J.Q. The rat in laboratory investigation. New York, Harfner Publishing Company, 1949. pp. 41-50.

Greene, G.C. Anatomy of mamimals. New York, Transactions of the American Philosophical Co, 1955. pp.177-235.

Habel, R. \& Stromberg, M.V. Anatomy and embryology of the laboratory rat. BioMed Verlag Worthsee, 1982. p.97116.

Lesbre, F.X. Précis d'anatomie comparèe dês animaux domestiques. Paris, Librairie J.B. Baillière et Fils, 1923. pp. 375-382.
Nayar, K. N. M.; Singh, G.; Singh, Y.; Singh, A.P. \& Singh, G. R. Comparative arteriographic anatomy of the abdominal viscera and lumbar region in goats, dogs. Pigs and rabbits. Indian Anim Sci., 53(12):1310-4, 1983.

Orsi, A. M.; Pinto e Silva, P.; Mello-Dias, S. \& Oliveira, M. C. Considerações sobre a ramescência da aorta abdominal do Hamster dourado (Mesocricetus auratus). Ver. Bras. Pesq. Med. Biol., 8(5-6):459-62, 1975.

Correspondense to:

Prof. Dr. José Ricardo de Carvalho Pinto e Silva

Departamento de Anatomia - Instituto de Biociências

Universidade Estadual paulista - UNESP

Botucatu - SP

BRASIL

Email: jotar@ibb.unesp.br

Received: 11-03-2008

Accepted: 23-08-2008 
